\title{
DETERMINATION OF PROCESSES OF USE, PRESERVING AND REPRODUCTION IN THE SYSTEM OF RENEWABLE NATURAL RESOURCES MANAGEMENT
}

\author{
Mikhail GAZUDA ${ }^{\text {, }}$ \\ Uzhgorod National University, Ukraine
}

\begin{abstract}
The purpose of the paper is to develop factor model of renewable natural resources management, specifying the assessment of the amount of resource, including the natural factor, consumption level and intensity of reproduction. Methodology. The survey is based on highlighting factors influencing the reproductive capacity of natural environment. It allows, on the base of taking into consideration reproductive abilities of resources and intensity of consumption, to substantiate three models for their use, including: heavy exploitation of renewable natural resources as the most commonly used model at the current level of development of society; model of reproductive use of natural resources, stipulating for the interference from the side of authorities and management, and the model of simple reproduction of renewable natural resources, at which the resource itself and the amount of its reproduction for the next period remain constant. Practical implications. The need is substantiated in implementation of the new model for determination of the processes of managing balanced use of natural resources, which will stipulate processes of reproduction in the sphere of natural management, form new approaches to environmental protection and promote the optimal ratio between the consumption and reproduction of natural resources. At this, the processes of natural reproduction are influenced by the amount of resource itself, intensity of its reproduction and level of consumption. The main objective of the managing bodies in the sphere of the use of renewable natural resources should be securing optimal ratio between consumption and reproduction of such natural resources. The efficiency of the implementation process and reproduction of natural resources presupposes providing their simple and extended reproduction, economic effectiveness and sustainability in allocation and use of such resources. This will have positive effect on ecological and economic security of the country as a whole and enhance implementation of basic provisions of the concept of balanced and sustainable nature management. Value/originality. Solving the problem of renewable natural resources preservation requires decreasing the level of consumption of natural resources to the level lower than their recovering capabilities are. Determination of the processes for securing reproductive capabilities of natural resources, their sustainable use and preservation substantiate the importance of the use of managerial approaches aiming to form favorable environment for their preservation and accumulation, and such way of using natural goods, that will provide for increase in consumption levels due to both advance growth of goods and their reproductive capabilities. The more the deviation between reproduction and consumption is, the more effective accumulation and reproduction processes will be, as well as consumption process in future.
\end{abstract}

Key words: determination of the management processes, balanced use of natural resources, factor model, consumption level, intensity of reproduction.

JEL Classification: Q28, 013

\section{Introduction}

Strong interrelation of events and processes taking place now within the provision of vital needs of society causes the timely character of studies in the sphere of using processes determination, preservation and reproduction of renewable natural resources. This also causes the need in developing a model for determination of management for balanced use of natural resources in various sectors of human's economic activity.
Substantial contribution in the study of scientific approaches to managing the processes of sustainable use and reproduction of natural resources was made by V. Golyan, M. Hvesyk (2007), B. Danylyshyn, O. Kucher (2005), P. Korenyuk (2002), I. Lukinov (1977), K. Rudyk (2012) and others. Comprehensive studies of the process of reproduction in agricultural nature management are in the works by V. Zaremba, V. Pavlov, Y. Fesina (2008).

Corresponding author:

${ }^{1}$ Department of Economy of Enterprise, Uzhgorod National University.

E-mail:mishagazuda@gmail.com 


\section{Determination of the process of natural resources sustainable use}

The general functional orientation of the mechanism of managing the use of renewable natural resources is the assurance of conditions of their sustainable use in different sectors of economic activity. The sustainable use of natural resources is related to three general directions (Paton, 2012): preserving their productivity, gradual increase of economic efficiency of their use, solving social problems of certain territories. Solving the existing problems in the sphere of the use of natural resources should be supported with making ecologically and socially oriented decisions. Therefore the changes in the system of natural resources management should concern transformations of the tools for preventing negative effects of the anthropogenic influence on natural resources and making for safe environment for people and nature.

The processes of determination of managing balanced use of natural resources, their reproduction and preserving are integral elements of management within the studied mechanism. It is important to note, that the model for determination of management of the balanced use of natural resources has to be based on complex analysis of the state of use of natural and resource potential, results of the assessment of efficiency of the use of renewable natural resources, taking into consideration the influence of natural factors. A new model for determination of processes of balanced use of natural resources management has to be implemented. It will define the selection of one of the models for development of renewable natural resources management: "consumption" model, at which natural resources are used in amount exceeding the scales of their reproduction; "reproduction model", at which reproduction processes are much more effective than consumption of natural resources; "environment protection" model, as a result of optimal balance between consumption and reproduction of natural resources.

Low development level of the economic system catalyzes the exploitative type of natural resources consumption, which is shown as an extensive natural management. This has a negative effect on the state of reproduction of natural resources and leads to their exhausting. At the same time, continuous increase of economic performances supports structural and technological changes and development of environmentally friendly technologies in manufacturing, decreases the pressure, done at natural and resource sphere. Thus, for example, development of agrarian economy and genesis of innovative solutions in the farm-machinery industry encouraged manufacturers of agricultural products to use move universal systems of machines in farming.

As a result, not only productive costs were lessened, but also the pressure of mechanicals on the soil have decreased, the conditions for growing have become better. Now their respective biologic parameters became subjects of complex systemic changes under the influence of anthropogenic factor. Here the Kuznets's phenomena of ecological curve has to be mentioned. He learned that increase of incomes in society together with decrease of differentiation automatically lead to quality improvement of environmental parameters. Thus, the social demands as to the ecological parameters of the life level increase together with the increase of economic well-being. Thus, we can make a conclusion, economic component of sustainable development of natural resources is the most important; therefore, the ultimate attention has to be granted to the opportunities of economic growth. The last will lead to increase of social parameters of life level and improvement of the state of environment. We consider that the transition of the consumption model of natural resources from technocratic to nature saving one is evident, as it reflects the natural origins of the human being. As human is one of the kinds of biosphere, its priorities cannot be treated as higher than the priorities of the biosphere as a system itself (Lukinov, 1977). Moreover, excessive consumption of natural resources causes breach in biochemical cycles of environment and its capability to assimilate and recover (Budzyak, 2011).

The study of scientific sources (Korenyuk, 2002; Hvesyk, Golyan, 2007; Rudyk, 2012; Danylyshyn, Kucher, 2005) reveals a common perception among scholars, that tools and objectives of the model of consumption of natural resources are oriented mostly at effective nature management. It supposes such activity of economic entities, which is aimed not only at satisfaction One's needs, but also at preserving (reproduction) of the components of environment. This aim is implemented through the economically correct use of natural conditions and constant keeping the regime of their reproduction. We agree with V. Baranovs'kyj, that the problem of rational use of natural resources has a strongly cut global and regional dimension and plays an important role in intensification of production (Baranovs 'kyj, 2001).

\section{Sustainable use of natural resources}

Sustainable use has a meaning of reasonable and careful attitude to the natural resources, which is gained on the base of economic harmonization and socio-ecological objectives and based on creating conditions for constant reproduction of natural resources and supporting preserving functions for them. Hence, sustainable use of natural resources is primary concerning the preservation of natural resources. Some scholars are expressing similar thoughts, considering sustainable natural management as a system of the use of natural resources, which is based on institutional norms in the sphere of natural management, stipulating their designated use, providing high efficiency of the use of natural resources, their preservation, defending the rights of owners and users of these resources under conditions of effective monitoring of formal and informal institutions (Pavlov, Zaremba, Fesina, 2008).

The function of sustainable use of renewable natural resources in the system of their management is aimed to 
provide development and support of the effective regime of both exploitation and reproduction of them, taking into account the objectives of sustainable development. It has to be mentioned, that for biological resources their sustainable consumption means the use of manufacturing wastes in the fullest extent possible.

In the sphere of agricultural production, considering its importance in the life of society and provision of its economic development, the resources used in this process have to be constantly reproduced of regenerated for their solidity.

Lukinov gives a broad explanation of the scale of reproduction process. He mentioned that reproduction covers all consistent stages of production, distribution and consumption and appears as a complex of naturally connected forms of economic circulation. Thus the scholar considered the process of reproduction of productive forces (including natural ones) and reconstruction of the system of production relations (Lukinov, 1977).

\section{Factor model of reproductive use of natural resources}

It's necessary to note that raising the question of reproduction of natural resources as a problem is obvious. The urgency of the issue is caused with the fact, that the scale of non-sustainable their use has a negative influence at both environment and economic sector. Therefore, the reproduction process is a general characteristic of renewable natural resources, which are having the ability of self-reproduction. To solve the problem of preserving natural resources, the consumption of them has to be decreased with the level, which is lower than their reproductive capacity is. The following factors are affecting the reproductive capacity of natural environment (Fig. 1).

Cyclic processes of consumption and reproduction are characterized with a tight cause-and effect relationship with the influence on both qualitative state of resource and on its reproduction. The amount of the natural resource itself, the intensity of its reproduction and the level of consumption have direct influence on the processes of natural reproduction. Factors, which can regulate the intensity of reproduction, are closely connected to the amount of resource, have natural qualities, are included in physiological, climate, ecological and other components, which have, though not in all cases, potential capabilities of regulation.

Therefore, three models of the resources usage can be formed taking into consideration the self-reproductive qualities of resources and consumption needs. The first is oriented at heavy exploitation of natural resources. It is the most common at the modern stage of societal development. The second one can be the base for implementation of reproductive use of natural resources. Its functioning has to be supported additionally with the mechanism of management in the sphere of the use of renewable natural resources. The last model will concern simple reproduction and consumption of renewable resources, at which the resource itself and the amount of its reproduction for the next period remain constant.

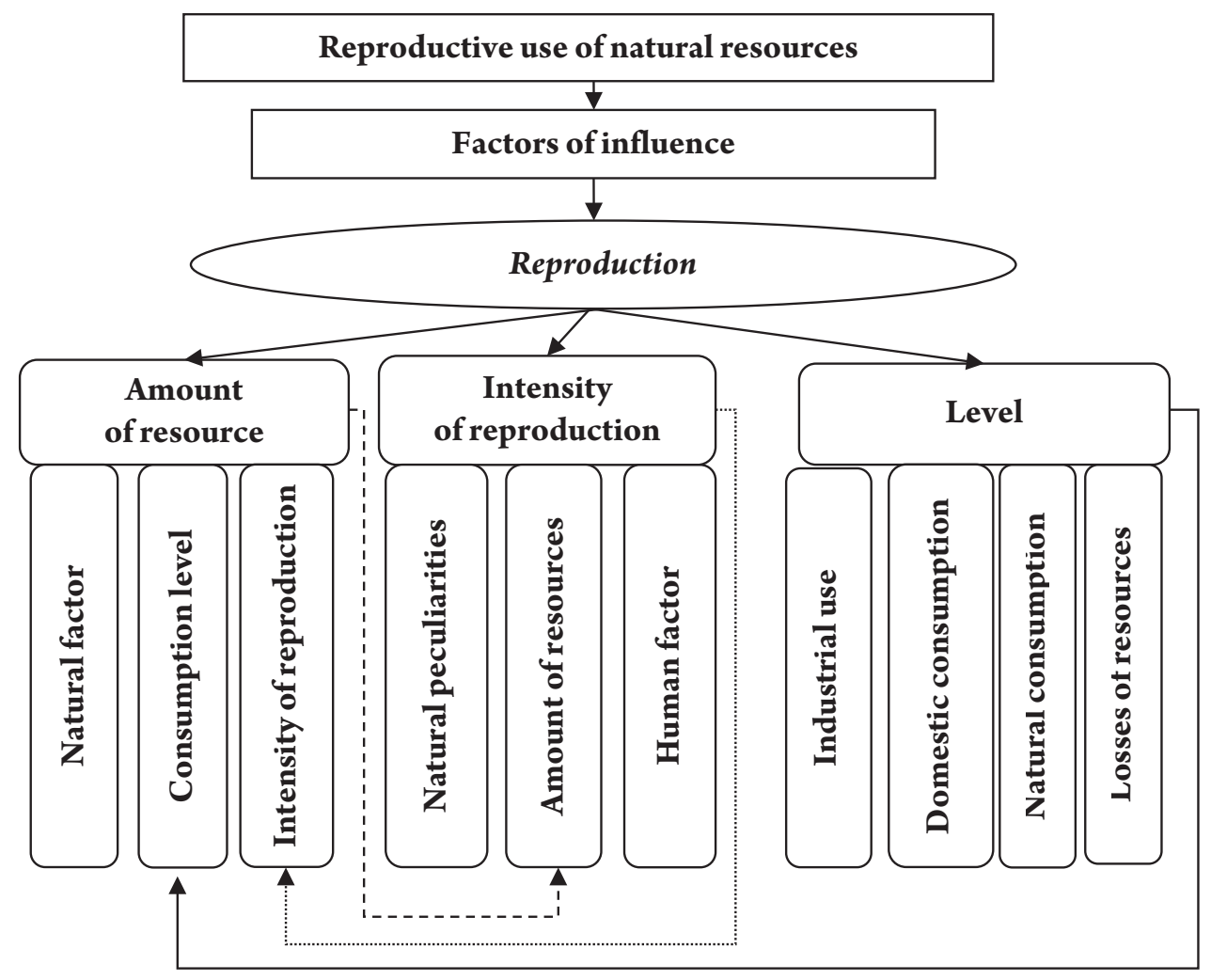

Fig. 1. Factor model of reproductive use of natural resources 
Considering the consumption and reproduction models, it should be mentioned, that the general task of the bodies of renewable natural resources management is to provide optimal ratio between consumption and reproduction of such renewable natural resources. Sustainable nature management has to be implemented at complete refusal to use elements of consumer-oriented approach of the use of renewable natural resources and at the platform of optimizing their use. Optimization itself gives the opportunity to balance interests in the sphere of natural resource management. Therefore, optimization gives the opportunity to define the threshold of the allowable level of economic activity at which the natural mechanism of reproduction of natural resources can be renewed. From the other side, optimization of consumption and reproduction models is a prerequisite for implementation of the model of preservation of natural resources.

Preservation of renewable natural resources has to be considered as a system of measures aimed to stand against the challenges of misbalancing socio-ecological and economic interests and secure natural resources from harmful activities, protect them from damaging, destruction or destruction.

As the results of the study of the sense of sustainable use, preservation and reproduction of natural resources show, all these notions are defined as both independent and interrelated elements of the system of renewable natural resources management. In particular, some thoughts are expressed, according to which protection of natural resources determines capabilities of sustainable natural resource marketing.

The result of implementation of the model for the use of renewable natural resources involves provision of economic efficiency and sustainability in allocation and use of these resources. The protection model is aimed at ecologization of environment, the main directions in which are: prevention of negative effects of anthropological influence on natural resources, creating safe environment for population and for the nature. The expected result of introducing the model of reproduction of renewable natural resource is provision of their simple and expanded reproduction. Such processes will have positive influence on ecological, economic safety of the country as a whole and will implement the basic provisions of the concept of balanced nature resources management.

Determination of renewable natural resources management shows the linkages of such systemic processes as development of natural resources as a material base for development of different sectors and kinds of economic activity. At this, the managerial level has the following elements: industrial use, having the basic reserves for saving natural resources; social and ecological use of resources has to be directed at economical consumption; part of resources is used with the nature itself for creation of other kinds of them; while the process has to be oriented at reproduction, balancing and harmonization of natural ecosystem; the losses of natural resources have to be minimized.

\section{Conclusions}

Therefore, reproductive natural management means management and use of renewable natural resources within the limits of their reproductive capabilities with the intent to preserve and accumulate them. It also means the way of using natural goods, at which increase in the rate of consumption is gained due to advance increasing of goods together with the increase of their reproductive capabilities. The more the deviation between reproduction and consumption is, the more effective accumulation and reproduction processes will be, as well as consumption process in future.

\section{References}

Paton, B. Y. (Ed.). (2012). Nacionalna paradygma stalogo rozvytku Ukrayiny. - Kyiv.

Lukinov, I. I. (1977). Vosproizvodstvo i tseny. - Moscow: Ekonomika.

Budzyak, O. S. (2011). Ekologobezpechne vykorystannya zemel: teoretichni ta praktychni aspekty. - Kyiv: Agrar Media Grup.

Korenyuk, P. I. (2002). "Ekologo-ekonomichnyj mexanizm racionalnogo vykorystannya pryrodno-resursnogo potencialu. Zb. nauk. Pr. Produktyvni syly i regionalna ekonomika. Part II, p. 50-59.

Hvesyk, M. A. and V. A. Golyan. (2007). Instytucionalna model pryrodokorystuvannya v umovax globalnyx vyklykiv. - Kyiv: Kondor.

Rudyk, K. V. (2012). Formuvannya efektyvnogo upravlinnya racionalnym zemlekorystuvannyam v systemi gospodarskogo mexanizmu. Naukovyj visnyk LNÅU. No 39, p. 175-180.

Danylyshyn, B. M. and O. O. Kucher (2005). Indykatory stalogo rozvytku i oxorony navkolyshnogo seredovyshha: osoblyvosti rozrobky ta vprovadzhennya. Agrobioriznomanittya Ukrayiny: teoriya, metodologiya, indykatory, pryklady: zb. nauk. pracz. - K: Nichlava, Vol. 1, p. 31-48.

Baranovskyj, V. (2001). Do koncepciyi perexodu Ukrayiny na model stalogo rozvytku. Ekonomika Ukrayiny. No. 7, p. 78-84.

Pavlov, V. I., Zaremba, V. M., and Y. G. Fesina. (2008). Instytuty ta instytuciyi agrarnogo pryrodokorystuvannya: regionalnyj vymir. - Luczk: Nadstyrya. 


\section{Михаил ГАЗУДА}

\section{ДЕТЕРМИНАЦИЯ ПРОЦЕССОВ ИСПОЛЬЗОВАНИЯ, ОХРАНЫ И ВОССОЗДАНИЯ В СИСТЕМЕ УПРАВЛЕНИЯ ВОЗОБНОВЛЯЕМЫХ ПРИРОДНЫХ РЕСУРСОВ}

Аннотация. Целью работы является разработка факторной модели воспроизводимого использования природных ресурсов, что предусматривает оценивание величины ресурса, в частности природного фактора, уровня потребления и интенсивности воспроизводства. Методология. Исследование основано на выделении факторов влияния на воспроизводственную способность природной среды, что позволило на основе учета свойств самовоспроизводства ресурсов и потребностей потребления, обосновать три модели их использования, в частности жесткую эксплуатацию возобновляемых природных ресурсов, как самую распространенную на современном уровне общественного развития, воспроизводимого использования природных ресурсов, что обусловлено целесообразностью поддержки со стороны властных и управленческих структур, а также модель простого воспроизводства и потребления возобновляемых ресурсов, когда неизменными остаются как сам ресурс, так и величина воспроизведения на последующий период. Практические последствия. Обоснована необходимость внедрения нового типа модели детерминации процессов управления сбалансированным использованием природных ресурсов, которая предопределяет воспроизводственные процессы в сфере природопользования, формирует новые подходы к охране окружающей природной среды и будет способствовать обеспечению оптимального соотношения между потреблением и воспроизводством природных ресурсов. При этом на процессы естественного воспроизводства непосредственно влияют величина самого природного ресурса, интенсивность его воспроизведения и уровень потребления. В сфере использования возобновляемых природных ресурсов главной задачей органов управления должно быть обеспечение оптимального соотношения между потреблением и воспроизводством таких природных ресурсов. Результативность процесса внедрения модели использования и воспроизводства природных ресурсов обуславливается обеспечением их простого и расширенного воспроизводства, экономической эффективностью и рациональностью в распределении и использовании этих ресурсов, что положительно повлияет на обеспечение как экологической, так и экономической безопасности страны в целом, и будет способствовать реализации основных постулатов концепции сбалансированного и рационального природопользования. Значение/оригинальность. С целью решения проблемы сохранения возобновляемых природных ресурсов необходимо довести потребление ресурсов до уровня ниже, чем их воспроизводственные возможности. Детерминация процессов обеспечения воспроизводственных возможностей природных ресурсов их рациональное использование и охрана обусловливают необходимость применения управленческих подходов в целях формирования благоприятной среды для их сохранения и накопления, и такой способ потребления природных благ, обеспечивать наращивание темпов потребления за счет опережающего роста, как самих благ, так и их воспроизводственных возможностей. Чем существеннее будет разница между восстановлением и потреблением, тем эффективнее станут процессы накопления и воспроизводства, а в дальнейшем и потребления. 